\title{
Education, Work Participation and Economic Growth in Indonesia
}

M.Kholik,Eddy Priyanto

(STIE Jaya Negara Tamansiswa Malang)

\begin{abstract}
This study examines government investment in education, job opportunities as reflected in work participation and its impact on economic growth by using secondary data from world banks using the moving average autoregression method. We find that work participation, education investment is positively related to economic growth.
\end{abstract}

Keywords : Education Investment, Economic Growth, Work Participation

\section{Background}

Students after graduating from college are expected to be able to enter the world of work based on their respective majors and study concentrations. Higher education graduates are expected to have sufficient human capital to work and contribute to the economy (Belasco et al,2020). Higher education graduates are expected to have a certain expertise in accordance with the field being studied. Education is one of the determinants of human capital owned by a person (Staneva,2020).

Investment in education is expected to be able to get a return on investment in accordance with that invested in education. With the increase in knowledge and skills, it is hoped that it will be able to increase a person's ability to get a job and be able to complete his job (Widarni \& Bawono,2020).

Theoretically, education investment, work participation and economic growth are positively related. This means that higher investment in education will increase work participation and economic growth (HATIRLI,2020).

\section{Literature Review}

Education policy is a very vital policy in the economy because education has an impact on the development of a country's human resources. Educational policies affect the quality of education and the number of school enrollments in a country. A high level of education reflects the level of education of a person, which reflects the social capital a person has based on educational quality standards (Smith ,2013).

Education from elementary school to college is very important in shaping a person's mental, character and skills.Education is one of the important mechanisms in building human capital. Human capital is needed in the world of work and it is very important to know someone's human capital. With high human capital, certain skills and expertise needed in the world of work will be formed so that in the 
end the best human capital owners will find it easier to get a job. So that education and work participation are positively related. When someone already has a job they will participate in the development and promote economic growth (Claxton \& Lucas,2015).

Economic growth itself is the result of all the economic activities of a country within one year. Where all citizens and humans who live in a country carry out economic activities and participate in the economy with their respective roles so that economic growth is formed (Gupta,2020).

\section{Research Method}

This study examines government investment in education, job opportunities as reflected in work participation and its impact on economic growth using secondary data from world banks using the moving average autoregression method with the following equation:

$\mathrm{GDPt}=\mathrm{Ct}+\beta 1 \mathrm{LPt} 1+\beta 2 \mathrm{EI} 2+\mathrm{et}$

Where,

GDP = Economic Growth

$\mathrm{C}=$ Constant

LP $=$ Workforce Participation

$\mathrm{EI}=$ Educational Investment

$\mathrm{e}=$ Error Term

\section{Result and Discussion}

The estimation results are as follows:

GDP $=-1.33529132783 e+13+435356963450 * E I+167582243536 *$ LP

From the estimation results, work participation (LP) and education investment (EI) have a positive relationship with economic growth. which is briefly described in Table 1 which describes the estimation results as follows:

Table 1. Estimation Results

\begin{tabular}{|l|l|l|l|l|}
\hline Variable & Coefficient & Std. Error & t-Statistic & Prob. \\
\hline C & $-1.34 \mathrm{E}+13$ & $4.59 \mathrm{E}+12$ & -2.910699 & 0.0097 \\
\hline EI & $4.35 \mathrm{E}+11$ & $6.64 \mathrm{E}+10$ & 6.557606 & 0 \\
\hline LP & $1.68 \mathrm{E}+11$ & $7.30 \mathrm{E}+10$ & 2.296623 & $3.46 \mathrm{E}-02$ \\
\hline R-squared & $8.20 \mathrm{E}-01$ & Mean dependent var & $2.03 \mathrm{E}+12$ \\
\hline Adjusted R-squared & $7.98 \mathrm{E}-01$ & S.D. dependent var & $7.30 \mathrm{E}+11$ \\
\hline S.E. of regression & $3.28 \mathrm{E}+11$ & Akaike info criterion & 56.00635 \\
\hline Sum squared resid & $1.83 \mathrm{E}+24$ & Schwarz criterion & 56.15571 \\
\hline Log likelihood & -557.0635 & Hannan-Quinn criter. & 56.0355 \\
\hline F-statistic & 38.60707 & Durbin-Watson stat & 1.482181 \\
\hline Prob(F-statistic) & 0 & \multicolumn{4}{|l}{} \\
\hline
\end{tabular}

Based on the estimation results described in Table 1., it can be seen that the R-square is very high so that changes in employment and education have a significant impact on economic growth which can be predicted in the study period in Figure 1 as follows: 


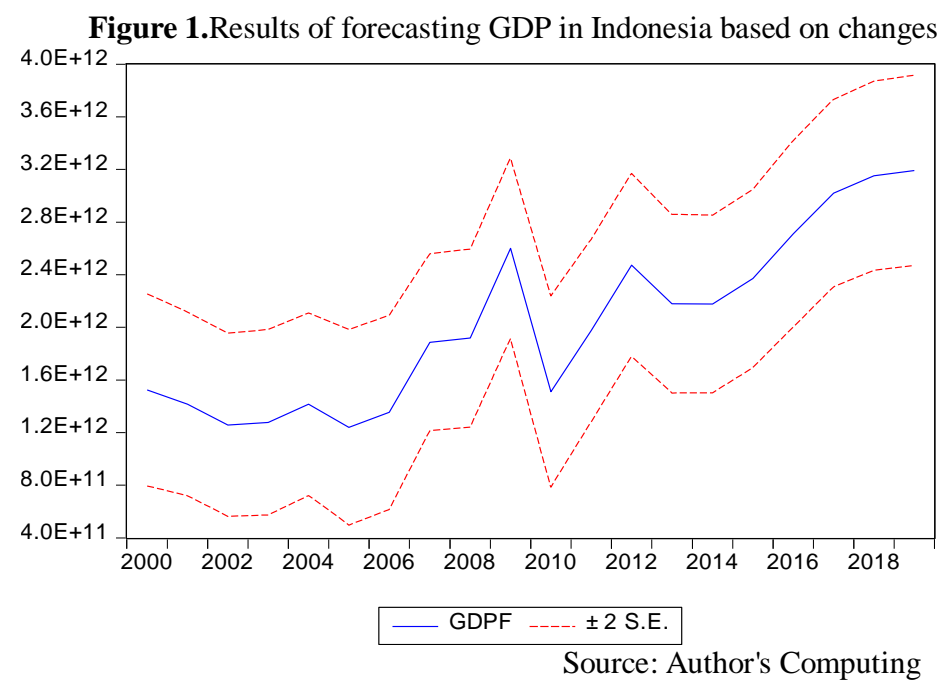

\begin{tabular}{|ll|}
\hline Forecast: GDPF \\
Actual: GDP \\
Forecast sample: 20002019 \\
Included observations: 20 \\
Root Mean Squared Error & $3.02 \mathrm{E}+11$ \\
Mean Absolute Error & $2.41 \mathrm{E}+11$ \\
Mean Abs. Percent Error & 14.13655 \\
Theil Inequality Coefficient & 0.070510 \\
$\quad$ Bias Proportion & 0.000000 \\
$\quad$ Variance Proportion & 0.049706 \\
$\quad$ Covariance Proportion & 0.950294 \\
Theil U2 Coefficient & 2.404537 \\
Symmetric MAPE & 13.46470 \\
\hline
\end{tabular}

Source: Author's Computing

Based on the forecast results in Figure 1, Indonesia's GDP in the 2000 to 2019 period of changes in economic growth as a result of changes in education and work participation tended to improve even though it was volatile.

\section{Conclusion}

Education is important in developing human resources to increase economic growth and development. Education is very important to educate the nation's life and develop knowledge and technology which in turn increases work participation and economic growth. As the economy grows and participation increases, the general welfare will also increase.

\section{Reference :}

Belasco,A., Bergman,D, Trivette,M.(2020).Colleges Worth Your Money: A Guide to What America's Top Schools Can Do for You.New York : Rowman \& Littlefield

Claxton,G., Lucas,B.(2015).Educating Ruby: what our children really need to learn. Carmarthen: Crown House Publishing

HATIRLI,S.A., KOÇ,Ş.A., DEMİREL,O.(2020).Theoretical And Applied Studies On Turkish Economy Vol. I. London : Ijopec Publication

Smith ,R.(2013).Education Policy: Philosophical Critique. Hoboken : John WIley and Sons

Staneva,M.(2020).Employment Alongside Bachelors Studies in Germany. Berlin : Springer

Widarni,E.L, Bawono,S.Human Capital Investment For Better Business Performance. Singapore: Triple Nine Communication 